\title{
Innovations that changed Mammalogy: metrification
}

\author{
Hugh H. Genoways, Robert M. Timm, ${ }^{* \oplus}$ and Suzanne B. McLaren \\ University of Nebraska State Museum, University of Nebraska-Lincoln, Lincoln, NE 68588, USA (HHG) \\ Natural History Museum and Department of Ecology \& Evolutionary Biology, University of Kansas, Lawrence, KS 66045, \\ USA (RMT) \\ Section of Mammals, Edward O'Neil Research Center, Carnegie Museum of Natural History, Pittsburgh, PA 15206, USA (SBM) \\ *Correspondent: btimm@ku.edu
}

Just as the writing of the Constitution of the young United States of America was being completed, the French were undertaking the planning and implementation of the metric system (International System of Units-ISU). The young nation has had more than a 230-year romance with this system of measures but the marriage has never been fully consummated as the United States remains one of only three nations in the world (with Liberia and Burma [Myanmar]) that has not made the use of the metric system mandatory. This history is filled with good intentions, miscalculations, national and international politics, names from history that you heard in grade school, missed opportunities, inertia, bad intention, mendacity, and delays. Mammalogists today never consider not using the metric system in their research, but in the 19th century this was an issue to be considered. Let us explore that history.

The U.S. Constitution, Article I, section 8 established the power of Congress to "fix the standard of weights and measurements." The young nation inherited the English units of weights and measures, which had evolved in England since the Middle Ages; however, there were no uniform standards across the 13 colonies. President George Washington almost immediately gave Thomas Jefferson, then Secretary of State, the responsibility to prepare a plan for standardized measurements to be presented to Congress. At the time, the primary concern was establishing an invariable standard of length, which preferably would be something occurring in nature. After the French Revolution, the French adopted for the metric system the term mètre (from the Greek for measure) for the basic unit of length, which they defined as equal to one ten-millionth of the distance between the North Pole and the Equator along the meridian through Paris. Jefferson was not satisfied with this decision because it meant that Americans would need to cross the Atlantic Ocean to have access to the primary standards. Instead, Jefferson developed his own decimal system of weights and measures based on standards that he had developed and adopted from the existing system. This plan was submitted to Congress on 13 July 1790, but was not taken up until 14 May 1796 when ultimately it was deferred and never resurrected (Treat 1971; Judson 1976; Harris 2021).

The next effort to standardize weights and measures in the United States started in 1816 under President James Monroe, resulting in the exhaustive 1821 Report Upon Weights and Measures to Congress by Secretary of State John Quincy Adams. Treat (1971:24) writing on the history of the metric system in the United States declared, "If any American work on the subject may be termed a 'classic' it is this report." Adams' report was so thorough that both the pro-metric and anti-metric forces used it to defend their positions, action consequently was slow in coming and ultimately changed very little. In 1830, a resolution of Congress directed the Secretary of the Treasury to survey the weights and measures used at the customs houses of the nation. The report found the standards varied widely from place to place (see Cardarelli 2003).

Louis McLane, Secretary of Treasury, in 1832 believed that he had the authority to select a standard set of existing weights and measures. He ordered Ferdinand Hassler of the Coast Survey to have a uniform and accurate set of these standards created and distributed to the custom houses (Fischer 1905; Treat 1971; Harris 2021); "U.S. customary units" was then the proper term for the system of weights and measures used in the United States. The only other significant action taken for the next 30 years was a joint resolution passed by Congress in 1836 directing that sets of the standards adopted by the Treasury Department be prepared and distributed to the states for their use and enforcement.

The early American scientists working on mammals were impacted by these decisions, as can be seen in their publications. George Ord (Ord 1815) and Thomas Say (Say 1822; Say and Ord 1825) working in Philadelphia - then the seat of science in the United States-were using English units for length measurements (feet and inches) in their mammalian research. Say's (1822) excellent description of the Cuban hutia (Isodon

(C) The Author(s) 2021. Published by Oxford University Press on behalf of the American Society of Mammalogists, www.mammalogy.org. 
pilorides $=$ Capromys pilorides) illustrates some of the issues of the day. He presented both external and cranial measurement, which was unusual for the time because skulls generally were mounted inside museum specimens, leaving only external measurements to be reported (Timm et al. 2021). The other noticeable difference in Say's work is that measurements were inches, many followed by a fraction. These fractions have a common denominator of 10 (or 100) because the measuring was being done in tenths of inches, so the numbers could be expressed in decimals thereby solving one of the major issues of working in English units.

Decimal inches were not used by all early American scientists, however. For example, John Bachman (1837a, 1837b, $1837 \mathrm{c}, 1839,1849$ ), working in South Carolina, wrote a series of important taxonomic publications on mammals using inches (") and lines ("'), including his major work with Audubon The viviparous quadrupeds of North America (Audubon and Bachman 1845-1848). The line as a unit of measure was used in the old English system, but it was dropped when the British Imperial system of units was put in place in 1826 (Treat 1971). Its value was usually $1 / 12$ of an inch but was also set at $1 / 10$ and several other less used values. It appears that Bachman was using a value of $1 / 12$ of an inch in his studies. The footinch-line system of measures gained use in English units in the late 1600 s.

Spencer F. Baird's seminal work on the mammals of North America (Baird 1859), following the midpoint of the 19th century, takes on a more modern appearance-the nomenclature is more familiar, the arrangement of accounts and their contents were more complete, there were both external and cranial measurements, many taken from animals preserved in fluid (undoubtedly the result of Baird's preparation manual-Baird 1852), and specimens were cited by their museum catalog numbers. However, when it came to the metrics, Baird stated: "The measurements have, in all cases, been made in English inches, divided either into lines or twelfths, or into 100ths. All the skulls, and in most cases the smaller skins, have been measured with dividers or callipers" (Baird 1859:xiv). Therefore, within this very important publication, measurements were not recorded in standard units and the implication is that external measurements were taken from dried skins, if not taken by the collector in the field. "Prior to the American Civil War not one piece of legislation calling for U.S. acceptance of the metric system had even been introduced in Congress" (Treat 1971:35) and as the review of the ongoing research of the time demonstrates, there was variation in standard weights and measures being used in the United States and the metric system was spreading across Europe (Appendix I).

Although the country's primary concern was elsewhere during the Civil War, interest and support for the metric system grew during this time. The efforts of three men-Alexander D. Bache, John A. Kasson, and Joseph Henry-resulted in the passage of a law in 1866 making the metric system legal for use in the United States. Bache, great-grandson of Benjamin Franklin, had been Superintendent of the Coast Survey since 1843, where his management of the Office of Weights and

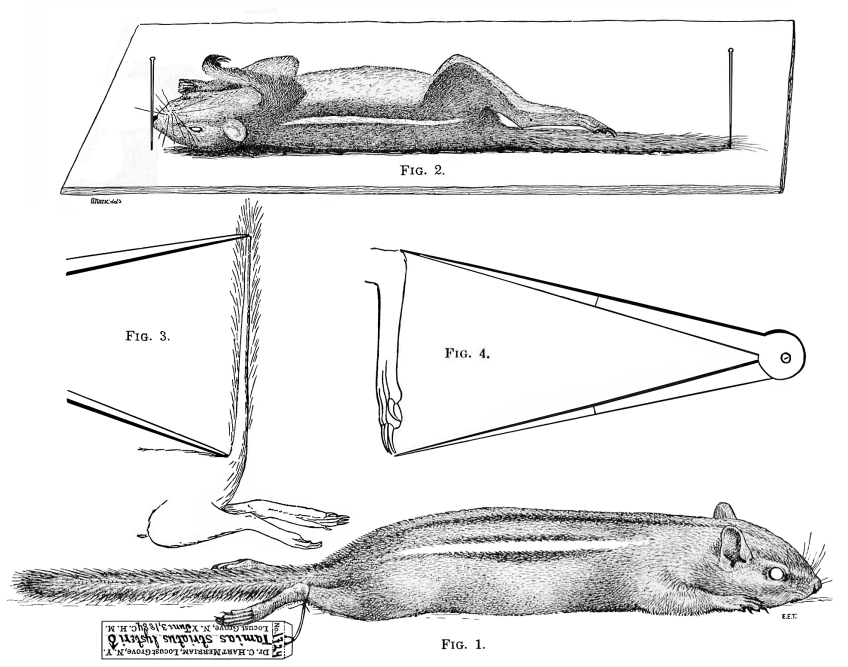

Fig. 1.-Merriam's (1889) figures from his preparation manual illustrating how to correctly take external measurements from small mammals. His instructions state, "The tools necessary for measuring mammals are a pair of compasses or dividers, a steel rule graduated in millimeters, and two large pins ... All measurements should give the distance in a straight line between the points indicated ... They [the measurements] should never be made with a tape-line over the convexities or inequalities of the surface" (Merriam 1889:3). Note the pins in board used to mark the tip of the nose and end of the caudal vertebrae and that distance being measured. The drawing is signed E. E. T. for Ernest Evan Thompson (1860-1946), a noted naturalist and wildlife artist who later published popular books under the name Ernest Thompson Seton. His best known scientific works are A list of the mammals of Manitoba (1886), Life histories of northern animals (1909), and Lives of game animals (1925-1929) (Sterling 2000). Seton was one of the charter and first Life Members of the American Society of Mammalogists.

Measures made him aware of the inadequacies of the customary system and the need for international standards. Kasson was a protégé of Abraham Lincoln, having been one of the principal authors of the Republican platform in 1860. Lincoln appointed Kasson First Assistant Postmaster General where he served until 1862, when he was elected to Congress from his home state of Iowa. He was selected as U.S. representative to the International Postal Congress in Paris in 1863, where he became fully aware of the needs of international standards for weights and measures for the development of the postal service. At Kasson's urging the House of Representatives created the Committee on a Uniform System of Coinage, Weights, and Measures, with him as its chairman (Treat 1971).

In 1863 another event occurred that was to have an impact on the decision to authorize the use of the metric system in the United States - by an act of Congress, the National Academy of Sciences was founded. The first group established by the Academy under the presidency of Bache was the committee on Weights, Measures, and Coinage, under the chairmanship of the eminent Joseph Henry, first Secretary of the Smithsonian Institution. This committee reported to Congress in January 1866 strongly supporting the metric system but warning that an 
abrupt change in the system of weights and measures could be disruptive to the nation. With this support, Kasson's committee moved the bill to adopt the metric system in the United States through the House and then the Senate. The bill was signed into law on 28 July 1866, but the final language made the metric system ". . . become an approved instrument of commerce ..." with the provision "It will not be forced into use . .." (Treat 1971:46). The metric system was to be taught in schools so that it would come into full use in the next generation, but there were no mandatory requirements or date for implementation of the system. Copies of the metric standards were to be obtained and distributed to the states (Treat 1971; Judson 1976).

Examination of Appendix I reveals that the legislation to make the metric system legal in the United States had no impact on scientists working on mammals in the United States. There were not many scientists studying mammals in the 1860s but we have found four who were, and all continued to use the U.S. customary system. One of the challenges that all scientists faced was the lack of scientific instruments with metric scales. It was not until 1871 that the W. \& L. E. Gurley Co., Troy, New York, offered a meter stick made of steel, marked in millimeters. The American Metrological Society was formed in 1873 with Fredrick Barnard, President of Columbia University, as the president, with the goal of promoting metric education and the metric system. In Connecticut, Birdsey Northrop, educator and reforestation promoter, convinced the state to contribute an exhibit of metric teaching apparatus to the U.S. Centennial International Exposition in Philadelphia in 1876. They were able to get a number of people and companies to contribute items, particularly helpful was the Stanley Rule \& Level Company of New Britain, Connecticut. Also formed in 1876, in response to the success of the metric exhibit, was the American Metric Bureau, incorporated in Boston, with Barnard as President and Melvil Dewey, of later library notoriety, as secretary handling the day-to-day business. This group's goal was to publish educational materials on the metric system and to supply metric items to schools. Thus, by the middle of the 1870 s, metric scientific instruments were being produced in America and being widely promoted and distributed by several groups (Kidwell et al. 2008).

In our survey of the literature, the first research paper on mammals that we found using the metric system was in 1870 , by J. A. Allen, in his review of the otariid seals (Appendix I). At the time, Allen was working at the Museum of Comparative Zoology at Harvard under the direction of Louis Agassiz. We have found no indication of why Allen selected the metric system for this book, although one might guess that Allen was influenced by Agassiz with his European background. Whatever the reason, Allen did not continue to use the metric system in subsequent publications until his major work on bison in 1876 and pinnipeds in 1880. In these same years, he was publishing in several places using the U.S. customary units, but particularly in U.S. Geological Survey reports, where he split his time as a special collaborator as well as maintaining a position at Harvard. If his work for the U.S. government under S. F. Baird influenced his selection of measurement systems, we have not been able to verify that, but it should be considered. Once Allen moved to the American Museum of Natural History in 1885, all of his publications used the metric system (Allen 1916).

An interesting contrast to Allen was Elliott Coues, who worked as an army surgeon until 1881 and as an independent scholar thereafter, but was associated with the Smithsonian Institution and S. F. Baird throughout his career. Coues primarily was an ornithologist but he published some extremely important reviews of mammal groups. Coues used the U.S. customary system throughout his career from his first paper on mammals from Arizona in 1867 to his last paper on Blarina in 1896, in Science. The juxtapositioning of the two measurement systems is striking in Coues' 1872 paper on the anatomy of Virginia opossum using the U.S. customary system, with an addendum detailing the anatomy of the brain of this species by Jeffries Wyman, an anatomist on faculty at Harvard, solely using the metric system (Appendix I).

Harrison Allen, a physician and anatomist on the faculty of the University of Pennsylvania, was the first American scientist to concentrate his research on the order Chiroptera. He began publishing in the 1860s and continued into the 1890s. His early research used the U.S. customary system until at least 1880 , when he was describing a fetal walrus giving measurements in inches and lines. There is a break in his research on mammals until 1890 when he returned to his work on bats, but this time he used the metric system for specimen measurements, including in his classic A monograph of the bats of North America in 1893.

The two remaining scientists in our survey came to research on mammals in the 1880 s, later than the previous group of authors. Frederick True was curator of mammals at the U.S. National Museum (1883-1909), but had studied invertebrates earlier in his career. Four of his papers from 1882 to 1884 reflect a mixture of both measurement systems, using decimal inches in two of the papers, centimeters in one, and combining the two in his short paper on the cinnamon bear. He used centimeters again in his two papers published in 1889 , but by 1890 , in his description of a new Phenacomys, he recorded measurements in millimeters and continued this practice in later publications.

C. Hart Merriam, who directed the U.S. Biological Survey for many years, was probably the key to the final acceptance and use of the metric system by scientists studying mammals in North America. He used both systems in some of his early works on mammals, but generally metric measurements were used first in the paper, with the equivalent value in the U.S. customary system being given second. No later than 1887 , he was solely using the metric system. Merriam's position in science gave his leadership in mammalogy an impact similar to that of S. F. Baird a generation earlier and, like Baird, one of his important influences was conveyed through a preparation manual for museum study skins (Fig. 1; Timm et al. 2021). In this manual, only the metric system was used (Merriam 1889). For mammalogy, we can say, with only a few exceptions, that metrification was in place by 1890 . 
The United States took its last major step toward metrification in the 19th century when in 1893

Thomas Mendenhall, the Superintendent of Weights and Measures, issued a Treasury Department Bulletin announcing that the U.S. prototype meter and kilogram [received in 1890] would henceforth be considered the nation's "fundamental standards of length and mass." Under the new procedures adopted by Mendenhall, units of the English customary system were defined not by their own standards but by carefully specifying what fraction of a meter would constitute a yard and what fraction of a kilogram would constitute a pound (Treat 1971:258-259).

Because the Mendenhall Order did not have congressional approval, its legal status was questionable, but it has not been challenged. The United States has continued to struggle toward full metrification through the 20th century and into the 21 st, but as of this writing it has not made the use of the metric system mandatory.

The metric system has advantages over all other systems of weights and measures because of its simplicity of use. It has a decimally based configuration with the base of 10 so that progressions of subunits and multiples of the standards for length, mass, and volume are in ratios of 1:10. There is a standard set of prefixes for the subunits and multiples. The ISU has only seven base units, with the two of interest here being the meter for distance and kilogram for mass. There also are derived units that have been built up from the base units using logical relationships, such as the unit of capacity, the liter, is one cubic decimeter. By contrast, "In the U.S. customary system, or the inch-pound system, more than 300 different units exist to measure various physical quantities" (Harris 2021). Finally, the most important reason to use the metric system of weights and measures is because it has achieved almost universal acceptance among the other nations of the world and it is part of the international language of science (Treat 1971).

In more than 230 years, the Congress of the United States has not exercised its constitutional duty of setting the standards for weights and measures for the nation. As a consequence, scientists, including mammalogists, are left with a dual system of weights and measures, always using the metric system for their research and teaching while they, and everyone else, are using the yard-pound-gallon system in their everyday lives. This dual system can be bothersome, but a real-world cautionary tale was presented to us by NASA. In September 1999, NASA lost a \$125-million Mars Climate Orbiter spacecraft because the navigation team used the metric system in planning, whereas the builder of the spacecraft furnished acceleration data in U.S. customary units (Hotz 1999). This caused the spacecraft to encounter Mars on a trajectory that brought it too close to the planet and was lost. Today all fields and aspects of science in the United States use metric units. Mammalogists should remember our forebears who helped forge the way forward for metrification of science.

\section{ACKNOWLEDGMENTS}

We thank D. Bennett for her efforts in crafting Merriam's (1889) figure for our use here and D. J. Schmidly for critically reviewing an earlier version of the manuscript.

\section{Literature Cited}

Allen, J. A. 1916. Autobiographical notes and a bibliography of the scientific publications of Joel Asaph Allen. American Museum of Natural History. New York.

Audubon, J. J., And J. Bachman. 1845-1848. The viviparous quadrupeds of North America. H. Ludwig, Printer. New York.

BACHMAN, J. 1837a. Description of a new species of hare found in South Carolina. Journal of the Academy of Natural Sciences of Philadelphia 7(2):194-199.

Bachman, J. 1837b. Observations on the different species of hares (genus Lepus) inhabiting the United States and Canada. Journal of the Academy of Natural Sciences of Philadelphia 7(2):282-361.

BaChman, J. 1837c. Some remarks on the genus Sorex, with a monograph of the North American species. Journal of the Academy of Natural Sciences of Philadelphia 7(2):362-402.

BaChMAN, J. 1839. Additional remarks on the genus Lepus, with corrections of a former paper, and descriptions of other species of quadrupeds found in North America. Journal of the Academy of Natural Sciences of Philadelphia 8(1):75-105.

BACHMAN, J. 1849. Notes on the generation of the Virginian opossum (Didelphis Virginiana). Proceedings of the Academy of Natural Sciences of Philadelphia 4:40-42.

BAIRD, S. F. 1852. Directions for collecting, preserving, and transporting specimens of natural history. Smithsonian Institution. Washington, D.C.

BAIRD, S. F. 1859. Mammals of North America. J. B. Lippincott \& Co. Philadelphia, Pennsylvania.

Cardarelli, F. 2003. Encyclopaedia of scientific units, weights and measures: their SI equivalencies and origins (M. J. Shields, trans.). Springer-Verlag. London, United Kingdom.

Fischer, L. A. 1905. History of the standard weights and measures of the United States. Bulletin of the Bureau of Standards 1:365-381.

HARRIS, W. 2021. Why isn't the U.S. on the metric system? https:// science.howstuffworks.com/why-us-not-on-metric-system.htm. Accessed 10 March 2021.

Hotz, R. L. 1999. Mars probe lost due to simple math error. Los Angeles Times, 1 October 1999. https://www.latimes.com/archives/ la-xpm-1999-oct-01-mn-17288-story.html. Accessed 2 March 2021.

Judson, L. V. 1976. Weights and measures standard of the United States: a brief history. U.S. Department of Commerce, National Bureau of Standards Special Publication 447:v+1-36.

Kidwell, P. A., A. Ackerberg-Hastings, and D. L. Roberts. 2008. Tools of American mathematics teaching, 1800-2000. Johns Hopkins University Press. Baltimore, Maryland.

Merriam, C. H. 1889. Brief directions for the measurement of small mammals and the preparation of museum skins. Division of Economic Ornithology and Mammalogy, U.S. Department of Agriculture. Circular 11:1-4. 
ORD, G. 1815. Zoology. Pp. 290-364 in A new geographical, historical, and commercial grammar (W. Guthrie, author/editor). 2nd ed. Johnson \& Warner. Philadelphia, Pennsylvania.

SAY, T. 1822. On a quadruped, belonging to the Rodentia. Journal of the Academy of Natural Sciences of Philadelphia 2(1):330-343.

SAY, T., AND G. ORD. 1825. Description of a new species of Mammalia, whereon a genus is proposed to be found. Journal of the Academy of Natural Sciences of Philadelphia 4(1):352-355.

Sterling, K. B. 2000. Seton, Ernest Thompson. American National Biography Online. https://todayinsci.com/S/Seton_Ernest/Seton Ernest-ANB.htm. Accessed 13 March 2021.
Timm, R. M., S. B. Mclaren, and H. H. Genoways. 2021. Innovations that changed mammalogy: museum study skins. Journal of Mammalogy 102:675-680.

Treat, C. F. 1971. A history of the metric system controversy in the United States. U.S. Department of Commerce, National Bureau of Standards Special Publication 345-10:vii+1-298.

Submitted 5 May 2021. Accepted 26 May 2021.

Associate Editor was Luis Ruedas.

\section{APPENDIX I}

Timeline showing the acceptance of the use of the metric system of measurements for their research by seven scientists studying mammals. During the period from 1859 to 1896, scientists worked on a wide diversity of vertebrates, with the study of birds probably more advanced than mammals. The seven scientists surveyed were Harrison Allen, J. A. Allen, Spencer Fullerton Baird, Elliott G. Coues, Ferdinand Vandeveer Hayden, C. Hart Merriam, and Frederick W. True.

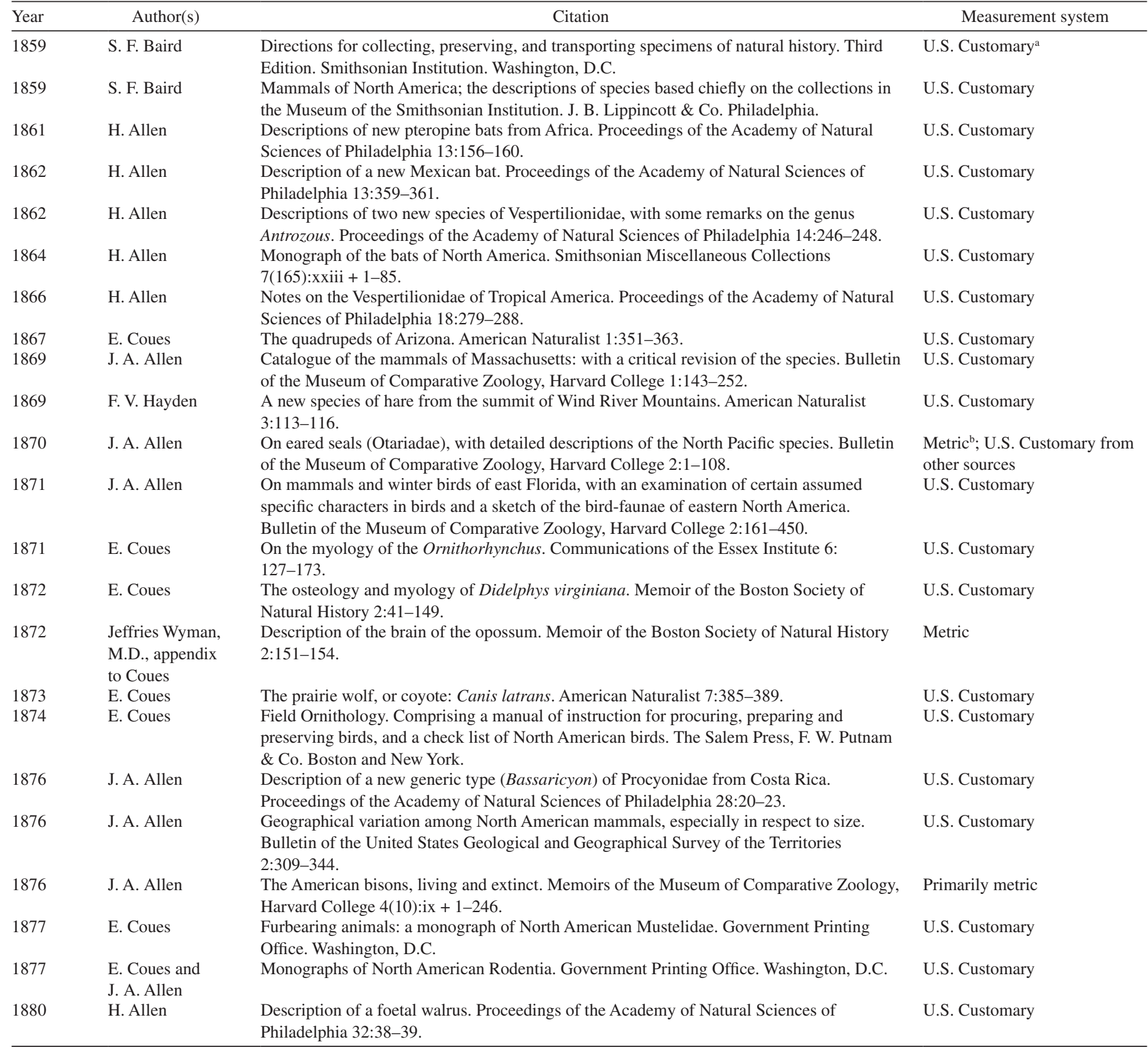


Appendix I Continued

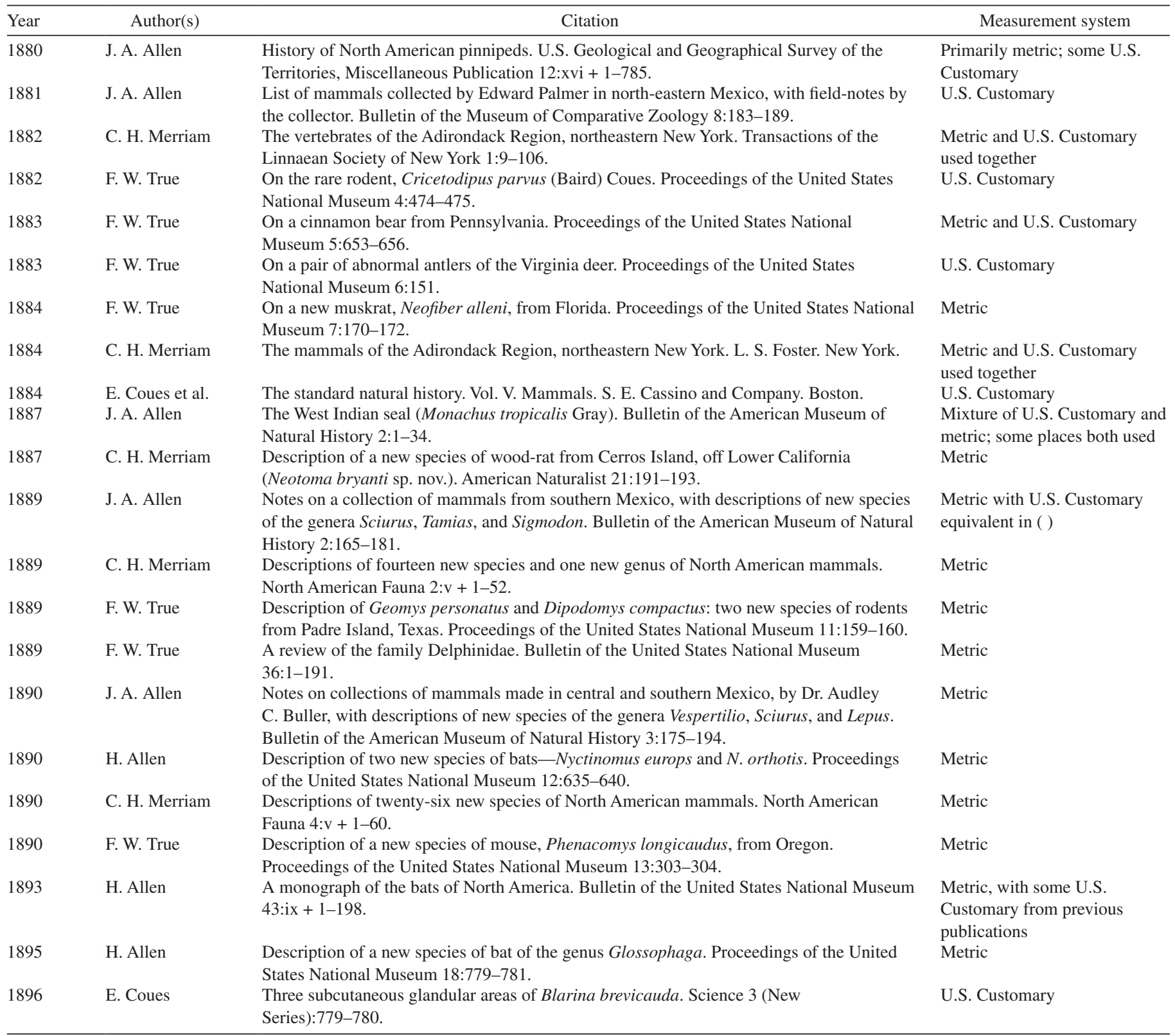

${ }^{a}$ U.S. Customary units of weights and measures.

${ }^{\mathrm{b}}$ International System of Units. 